\title{
ケロイド肥厚性㓔痕治療の現状とトラニラストを使用した イオン導入法による治療経験
}

\author{
茂木定之・信岡乃理 ${ }^{* 11}$, 生田義和 ${ }^{* 2)}$, 村上照夫・高野幹久・矢田 登*3)
}

The present clinical therapy for keloids and hypertrophic scars and experience of iontophoretic therapy with tranilast

Keloids and hypertrophic scars, especially keloids, are clinically intractable scars caused by an abnormal proliferation of fibroblasts and excessive production of collagen. The present clinical therapy for such scars is described briefly, and the feasibility of iontophoretic therapy with tranilast was examined in hairless rats and patients with scars. A drug electrode containing $12 \mathrm{mg}$ tranilast, which was dissolved in $1.5 \mathrm{ml}$ of ethanol/water ( 8 : $2 \mathrm{v} / \mathrm{v}$ ) mixture, was placed on the dorsal skin surface of anesthetized rats or the affected parts of patients, and connected to the negative pole. An electric current was pulsed through at one min intervals. The in vivo current density was almost comparable between intact skin surfaces of healthy volunteers and keloids/hypertrophic scars of patients. Tranilast given iontophoretically $(2 \mathrm{~mA})$ a period of $30 \mathrm{~min}$ a week reduced the patients' complaints of pain and itching after only one or two treatments.

Thus, the transdermal iontophoretic delivery of tranilast may be a useful treatment for keloid and hypertrophic scars, particularly for relieving pain and itching, and is more beneficial than tranilast given orally. Some discussions were also made in the present report.

Sadayuki Shigeki $\cdot$ Nori Nobuoka ${ }^{* 11}$, Yoshikazu Ikuta ${ }^{* 2)}$, Teruo Murakami . Mikihisa Takano $\cdot$ Noboru Yata*3) key words : keloids, hypertrophic scars, transdermal therapy, tranilast, iontophoretic delivery

*1) Division of Plastic and Reconstructive Surgery, *2) Department of Orthopedic Surgery, ${ }^{-3}$ Department of Biopharmaceutics, Institute of Pharmaceutical Sciences, Hiroshima University School of Medicine

-1) 広岛大学医学部整形外科- 形成外科診康班, ${ }^{-21}$ 同 整形外

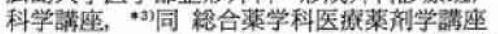
Offprint requests to: Sadayuki Shigeki, M. D., Division of Plastic and Reconstructive Surgery, Hiroshima University School of Medicine, 1-2-3 Kasumi, Minamiku, Hiroshima 734

\section{ケロイド肥厚性瘦痕治療方法の現状}

創傷の治痛過程の異常で痒痕組織が著明に增殖 し, 周囲の正常皮有をも侵裂し皮虔面より隆起し たものがケロイドであり, もとの創傷の範囲を越 えずに隆起したものが肥厚性痗痕である ${ }^{11}$. しか し, ケロイド肥厚性緳痕は, 決して皮有よりの隆 起という整容的問題だけではなく, 疼痛, 搔痒感 など日常生活上障害となる自覚症状をしばしば有 する，ところが，これらの症状は客観的に確認し 理解することが困難なため, ケロイド肥厚性㓔痕 の障害は，単に外見的な問題だけであるとして軽 視されがちである。 また, ケロイド肥厚性瘵痕発 生の根本的原因がいまだ不明㙩であるため, 確実 な治療方法がなく, 積極的な治痛を行おうとする 医療関係者も少ない。これに対して，隆起し目立 つケロイド肥厚性㓔痕のため, 家族, 友人と入浴 や海水浴ができない, 衣服やシートベルトが当 たって痛い, 搔痒感が強く一日中気になる, 搔い ていて傷が生じるなど, 患者の訴えは切実であり， 日常生活が大きく制限されていることが多い.

ケロイド肥厚性痏痕の治療は, 保存的治療と外 科的治療にわけられるが, 保存的治療には, 薬物 療法, 圧迫療法, 放射線療法がある 2 . 薬物療法と しては, ペリン類似物質やステロイド斉の外用, ステロイド斉の注射, 内服薬の服用等がある.

このなかで，ステロイド剂の患部への直接注射 は，比較的効果が期待できるものと考えられてい る.これは, 数週間に一度, トリアムシノロンア セトニド懸濁液をケロイド内に注射し, 効果があ らわれるまで繰り返すものである。しかし，硬い ケロイド組織内に注入するため, 局所麻酔薬と混 合投与しても著明な疼痛を伴う, 周辺の皮㖇に薬 液が浸潤した場合正常皮㖇の萎縮を起こす，女性 
では月経異常を起こす場合があるなどの欠点を有 する3). 数力月間注射をつつ゚けても改善しない症 例もあり，また注射を中止すると症状が再発する ことがある.

内服薬は, 現在唯一, トラニラストが使用され ている. トラニラストは内服投与という利便性は あるが, 一日 3 回の服用を要し, 数力月にわたり 内服をつづける必要がある。このため, 患者のな かには服用を忘れたり, 途中で勝手に服用を中止 する者がいる，さらに，全身投与のため，膀胱炎 症状や消化器症状などの副作用の発生に常に注意 しなければならない.

圧迫療法は, 患部に貼りつけたスポンジをテー プや弾力包带, サポーターで固定する方法が中心 である，長期間つづける必要はあるがそれなりに 効果があり, 保存的治療単独としても, あるいは 外科的治療後にも行われている4).ただし,かさば り衣服が着にくいと不満を訴える患者が時にお り, 特に関節部の圧迫固定では学校や会社での活 動が制限されることがある、最近は, シリコンジェ ルシートが利用しやすくなったため, これによる 治療も行われる.

シリコンジェルシートには, (1) 粘着性があり使 いやすい, (2) 圧迫の必要がなく貼付するだけでよ い, (3) まったく疼痛を伴わない, (4) 患部への適 合性が比較的良好である, (5) 耐久性があり 1 枚の シートを繰り返して使用できるなどの特徴があ り, 自覚症状の強いケロイド肥厚性廄痕の症例で

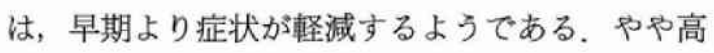
価であるが，患部が小さければ切って使用でき， 1 枚で数力月間利用することも可能である. しか し, 密閉性がよいため, 皮阅炎を起こす可能性に は注意が必要である。

放射線療法としては, X線療法, ラジウム療法, アイソトープ療法がある ${ }^{3)}$. 外科的治療後に使用 されることが多いが, 安全性に対して強く不安を 訴える患者もいる.

外科的治療は単独で行うことは少なく, 特にケ ロイドでは術後保存的治療の薬物療法, 圧迫療法, 放射線療法を併用することが多い.手術方法には, 切除後の単純縫縮, $Z$ 形成術, 遊離植皮術等があ
るが2,3)，ケロイドは術後に再発や手術前より痽痕 が増悪することもあり, 安易な手術は非常に危険 である.

このように，ケロイド肥厚性瘏痕の治療には難 渋しているが，体表面の疾患であるため，患部だ けに治療効果のある薬物を簡単に投与できる手法 があれば，患者への過重な負担もなく，患者医療 関係者双方にとって治療しやすいと考えられる.

筆者らは, 局所麻酔楽, ステロイド剤, 血管拡張 剤等の送達方法の一つとして知られているイオン 導入法沙にこの可能性があるのではないかと考 え, トラニラストを用いへアレスラットによる基 礎実験を行い，この結果をもとに健康な被検者に よる電流值測定, ケロイド肥厚性痗痕患者への臨 床応用を行った。以下に, 若干の文献的考察とと もに報告する。

\section{イオン導入法による治療}

イオン導入法とは, 薬液電極パッドに薬物を溶 液として負荷したのち，薬物と同符号の電極を接 続した楽液パッドと，アースとして貼付した対極 板との間に通電を行い, 反発遊離した薬物を薬液 パッド周囲組織に拡散させる手法である ${ }^{6,7)}$. すな

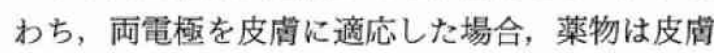
組織内に送達される。この手法の利点として, (1) 普通皮虞を透過しないイオン型薬物の皮首透過性 を改善する, (2) 通電する電流值を変化させること で薬物透過量の制御が可能である, (3) 薬物供給の 任意の中断が可能である $(\mathrm{ON}, \mathrm{OFF}$ 機能を有す る)などがある.たた゚し, 通電による皮膚障害の可 能性に注意を要すること, イオン導入法用の装置 が高価で, 専用の薬液パッドが必要なことが久点 としてあげられる。

つぎに，各項目別に述へる，なお，実験動物で の基礎実験は, 一部本誌に報告した ${ }^{8)}$.

\section{(1) 薬液調整}

トラニラスト (キッセイ薬品工業(排)より供与) は, pKa3.7 の弱酸性イオン型薬物である. 従来, イオン導入法において薬物は水溶液として用いら れてきた，トラニラストは，水に対する溶解度が きわめて低く $\left(0.025 \mathrm{mg} / \mathrm{ml}\right.$, 温度 $\left.25^{\circ} \mathrm{C}\right)$, 投与量 


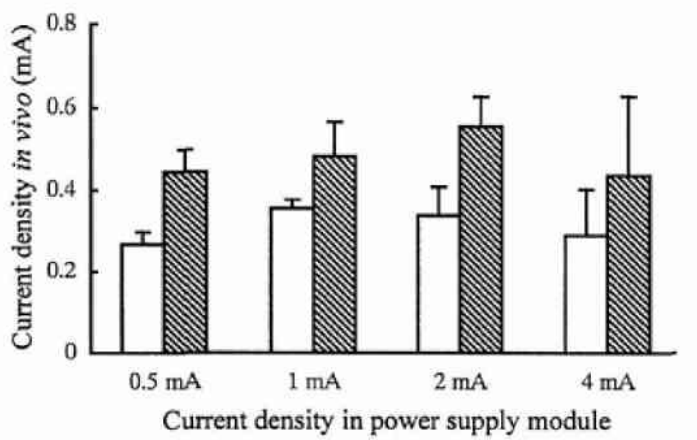

図 1 In vivo current density during iontophoresis of tranilast in hairless rats The current density in power supply module was set at $0.5,1,2$, or $4 \mathrm{~mA}$. Drug electrode contained $12 \mathrm{mg}$ tranilast dissolved in $1.5 \mathrm{ml}$ of ethanol/water $(8: 2 \mathrm{v} / \mathrm{v}$ mixture. $\square: 0.5 \mathrm{~min}, \mathbb{N}: 30.5 \mathrm{~min}$ after starting of iontophoresis. Each value represents the mean \pm SE of 3-4 trials.

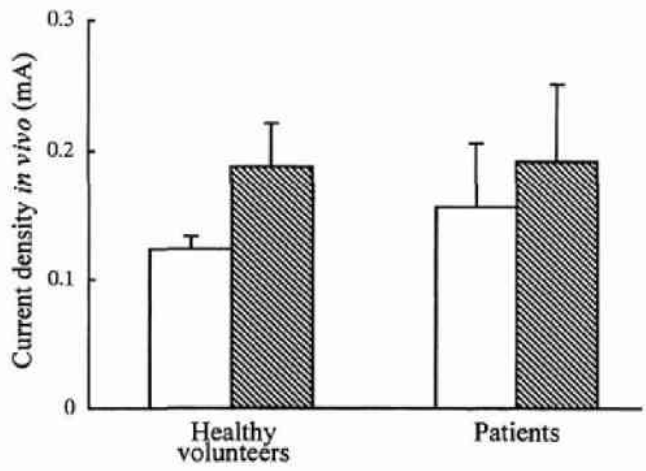

図 2 In vivo current density during iontophoresis of tranilast in healthy volunteers and patients with keloids or hypertrophic scars

The current density in power supply module was set at $2 \mathrm{~mA}$. Drug electrode contained $12 \mathrm{mg}$ tranilast dissolved in 1.5 $\mathrm{ml}$ of ethanol/water $(8: 2 \mathrm{v} / \mathrm{v})$ mixture. and was placed on shoulder girdle in 3 healthy volunteers, or affected parts in 4 patients, respectively. $\square: 0.5 \mathrm{~min}, \mathbb{\mathbb { N }}: 10.5$ min after starting of iontophoresis. The distance between a drug electrode and a dispersive pad was $20 \mathrm{~cm}$ in all cases. Each value represents the mean $\pm \mathrm{SE}$.

を確保するためには，薬物溶解度の改善が必要で

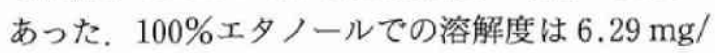
$\mathrm{ml}$ であったが，エ夕ノール/水混合液 $(8: 2 \mathrm{v} / \mathrm{v})$ では溶解度は $8.93 \mathrm{mg} / \mathrm{ml}$ と増大することが認め られた。このため, 本研究では上記混合液を溶媒

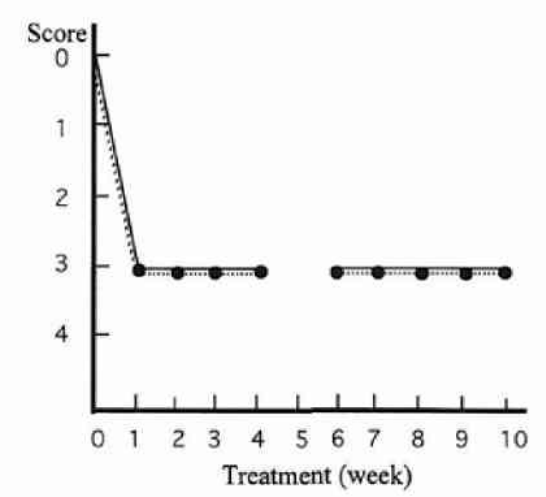

图 3 Patient's complaints after weekly iontophoretic treatment with tranilast (12 mg tranilast each, 30 min a week)

- : pain, $\cdots:$ itching. Scores for pain and itching : $0=$ no effect $: 1=$ slight reduction $; 2=$ moderate reduction $; 3=$ clear reduction $; 4=$ disappearance of pain and itching.

として用い, トラニラストの $8 \mathrm{mg} / \mathrm{ml}$ の溶液を調 整し, イオン導入法薬液として使用した.

\section{（2）ラットにおける予試験/電流值測定}

体重 $250 \mathrm{~g}$ 前後の雄性へアレスラットを使用 し, 実験前日に注意樑く剃毛を行った. ペントバ ルビタールで麻酔したのち, 体温確保の目的で $37^{\circ} \mathrm{C}$ に保温した water bed 上に固定した. トラニ ラスト溶液 $1.5 \mathrm{ml}$ (トラニラスト量 $12 \mathrm{mg}$ )を含む 薬液電極パッド (Trans $Q_{1}$ Iontophoretic Drug Delivery Electrode, Iomed, Inc.) をへアレスラッ ト背部に, 対極板(Dispersive Ped, Iomed, Inc.) を腹部に貼付した。薬液電極パッドはイオン導入 法装置の陰極に, 対極板と電流計は直列に配線し 陽極に接続した。通電は 1 分間隔の間歇型とし, イオン導入法装置の電流值を $0.5,1,2,4 \mathrm{~mA}$ に設 定し, ヘアレスラット体内に流れる電流を測定し た(図1).

装膡の出力を 0.5 から $4 \mathrm{~mA} へ$ と変化させて も, ヘアレスラット体内に流れる電流值は 0.17 か ら $0.63 \mathrm{~mA}$ の範囲内で, 各設定值間において有意 の差は認められなかった. しかし, 以前報告した トリアムシノロンアセトニド(溶媒として $\mathrm{N}, \mathrm{N}-$ dimethylacetamide/水, $7: 3 \mathrm{v} / \mathrm{v}$ を使用)の結 果 ${ }^{8,9)}$ と同様に, 電流值の経時的上昇が確認され 


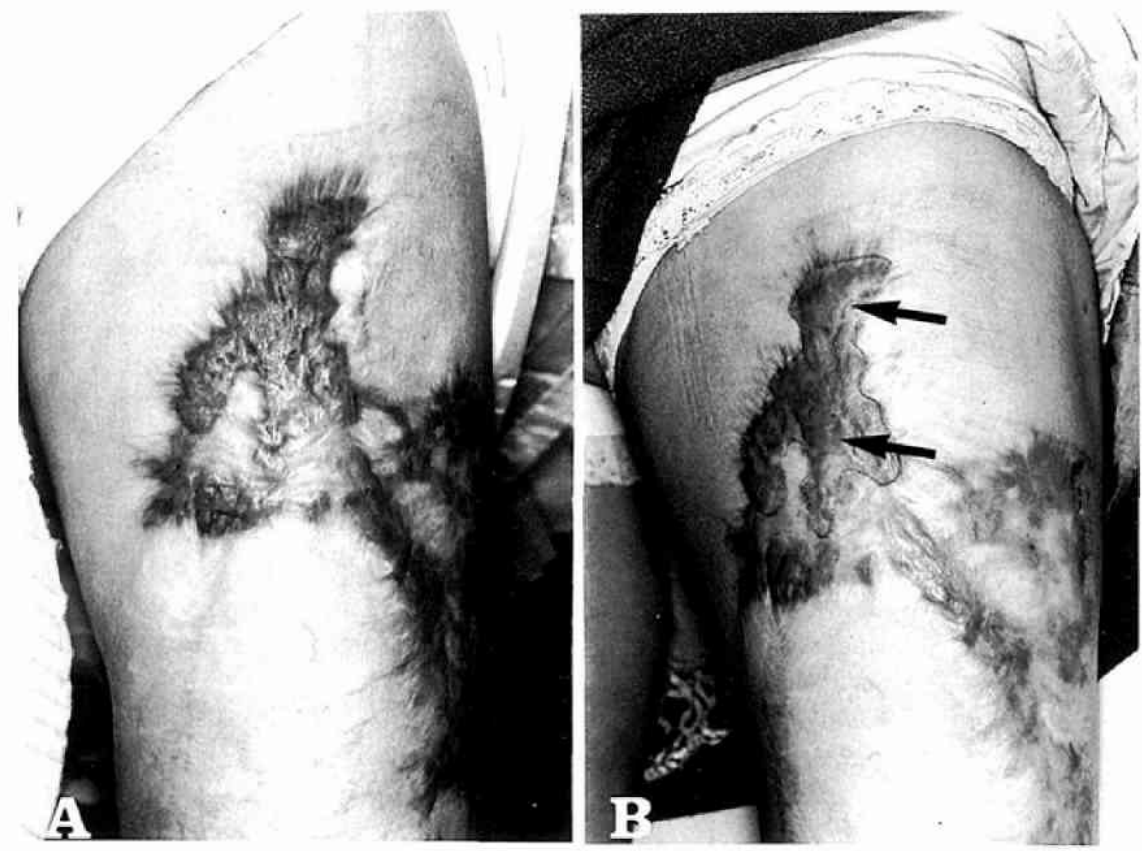

図 4 Photographic observation of hypertrophic scars A : before treatment, B : after treatment (12 weeks). Drug electrode contained $12 \mathrm{mg}$ tranilast dissolved in $1.5 \mathrm{ml}$ of ethanol/water $(8: 2 \mathrm{v} / \mathrm{v})$ mixture. Treatment was carried out at $2 \mathrm{~mA}$ of power supply module for a period of $30 \mathrm{~min}$ a week. Arrows indicate the partial flattening of the affected parts.

た。これは，エタノールがまず吸収され薬液パッ ド中の水分含量比が増大すること，および間歇型 通電法のためではないかと考えている。 また， 2 $\mathrm{mA}$ で 30 間分のイオン導入法処置により,トラニ ラストの負荷量の $1.7 \%$ が皮膚組織に移行し た ${ }^{8)}$. イオン導入法後のへアレスラット皮有組織 を組織学的に検討したが，いずれの条件において も皮膚障害は観察されなかった。

\section{（3）ヒトにおける電流值の検討}

3 人の健康な被検者 (女性, 20 歳, 22 歳, 25 歳) について薬液パッドと対極板間の距離の影響を検 討し, 患者(男性 24 歳：胸部ケロイド, 男性 10 歳：肩甲帯部肥厚性瘯痕, 女性 77 歳：大腿部肥厚 性痗痕, 女性 34 歳：肩甲带部肥厚性瘕痕)に扔け る測定值と比較した。

被検者では, トラニラストを含む薬液パットを 肩甲帯部に貼付し，対極板を薬液パッドから 10 $\mathrm{cm}, 20 \mathrm{~cm}, 30 \mathrm{~cm}$ の距離で上肢に貼付し電流值を 測定した. 出力電流值は $2 \mathrm{~mA}$ に設定した. その結
果，いずれの被検者においても，薬液パッドと対 極板間の距離の違いによる影䇺は認められず, 電 流值はほほ一定の值を示した。また，健康な被検 者と患者間で測定值に差は認めず(図 2)，ケロイ ド肥厚性㾲痕の患者においても，電流值は十分に 碓保されていた。

\section{（4）臨床への応用}

\section{代表的な症例を示す.}

症例 : 77 歳, 女性. 胸部の創に対して, 左大腿 部前面より遊離分層植皮術が行われたが，その採 皮部が次第に肥厚性瘢痕になった症例である。疼 痛と搔㾕感が強く, 十分な説明と患者の了解を得 たのち，イオン導入法によるトラニラストの経皮 送達治療を行った。治療は週に一度, $2 \mathrm{~mA} て ゙ 30$ 分間通電し, 1 回のトラニラストの投与量は 12 $\mathrm{mg}$ とした. すなわち, トラニラストを $8 \mathrm{mg} / \mathrm{ml}$ の濃度でエタノール/水 $(8: 2 \mathrm{v} / \mathrm{v})$ の混合溶媒に 溶解し, 薬液パッドに $1.5 \mathrm{ml}$ 注入した。最初のイ オン導入法後, 自賞症状が 5 日間軽隇し，4 回目 


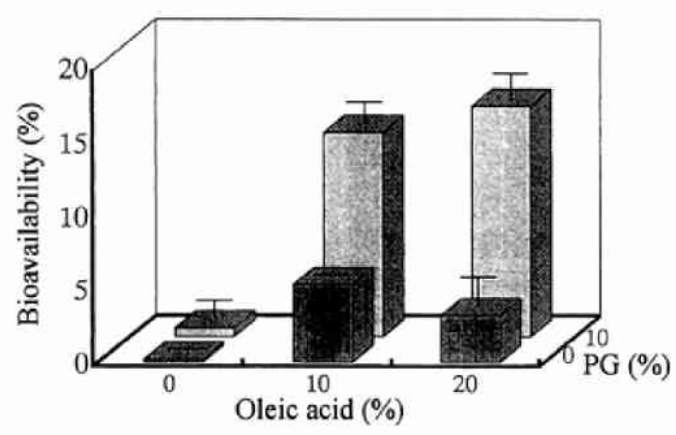

図 5 Enhanced transdermal bioavailabilities of tranilast by oleic acid and/or propylene glycol(PG) in Wistar rats

Tranilast ethanol solution containing oleic acid and/or propylene glycol was topically applied for 5 hour at a area of $1.5 \times 1.5 \mathrm{~cm}^{2}$ with a dose of $1.5 \mathrm{mg} / 0.1 \mathrm{~g}$ solution $/ \mathrm{rat}$. The skin surface was covered with polyethylene film during the experiment. Bioavailability was estimated by comparing the AUC value of tranilast in plasma between intravenous administration and topical application. Each value represents the mean $\pm \mathrm{SE}$ of 3 trials.

の処置後では 7 日間にわたり軽減した。自覚症状 が改善したため, 患者の判断で治療を一時中断し たが, その後症状が再発し, 再度イオン導入法治 療を受けた. 合計 12 回の治療後では, 瘢痕の発赤 と硬度が減弱し, 部分的な平担化も確認された (図 3,4).

（5）ラットにおける吸収促進剤併用の検討

薬物の経皮吸収を改善する方法として，イオン 導入法のほかに吸収促進剤の併用 ${ }^{10} や$, リポソー ムを担体とした皮膚局所への薬物滞留型送達 法 $^{11,12)}$ 等が報告されている. 筆者らは, トラニラス ト/エタノール溶液に, 吸収促進剤として $10 \%$ ま たは $20 \%$ オレイン酸および $10 \%$ プロピレングリ コールを添加することにより，ラット皮䇣からの トラニラストの吸収が有意に改善されることをす でに報告した ${ }^{13)}$. 20\%オレイン酸と $10 \%$ プロピレ ングリコールの併用では， 5 時間の密封療法処置 下で投与量の約 15\%が全身循環血に吸収され(図 5), また皮䪭組織中のトラニラスト濃度も, トラニ ラスト/エタノール溶液のみの場合にくらべ約 30 倍増加することが認められた。 オレイン酸は, 角 質細胞間脂質の配列秩序の乱雑化等の作用があ
表 1 Concentration of tranilast in keloids or hypertrophic scars after $30 \mathrm{~min}$-iontophoretic treatment ( $12 \mathrm{mg}$ tranilast, $2 \mathrm{~mA}$ )

\begin{tabular}{|c|c|c|c|c|c|}
\hline $\begin{array}{l}\text { Case } \\
\text { No. }\end{array}$ & Sex & $\begin{array}{c}\text { Age } \\
\text { (years) }\end{array}$ & Site & $\begin{array}{l}\text { Weights } \\
\text { of scar } \\
(\mathrm{g})\end{array}$ & $\begin{array}{c}\text { Concentration } \\
\text { of tranilast } \\
(\mu \mathrm{g} / \mathrm{g})\end{array}$ \\
\hline 1 & $\mathrm{~F}$ & 28 & $\begin{array}{l}\text { Pubic } \\
\text { region }\end{array}$ & 9.29 & 2.33 \\
\hline 2 & $\mathrm{~F}$ & 28 & Abdomen & 0.41 & 7.07 \\
\hline 3 & $\mathrm{~F}$ & 17 & Knee & 0.60 & 21.3 \\
\hline 4 & F & 22 & Leg & 1.58 & 16.4 \\
\hline 5 & $\mathrm{~F}$ & 59 & Abdomen & 1.90 & 3.13 \\
\hline 6 & $\mathrm{~F}$ & 59 & Abdomen & 1.36 & 2.38 \\
\hline 7 & $\mathrm{~F}$ & 14 & Knee & 1.22 & 10.6 \\
\hline 8 & M & 20 & Chest & 0.93 & 1.84 \\
\hline 9 & M & 20 & Chest & 1.82 & 1.85 \\
\hline
\end{tabular}

Case No. 1 7: hypertrophic scars.

Case No. 8 9: keloids.

Case No. 1 $\sim 4:$ treated with tranilast alone.

Case No. 5 9: treated with tranilast containing $5 \%$ oleic acid and $5 \%$ propylene glycol.

Scars were excised within $2 \mathrm{hr}$ after iontophoretic treatment.

り，主に角質層からの薬物の経皮吸収を促進する と考えられている ${ }^{14,15)}$.

そこで， $5 \%$ オレイン酸と $5 \%$ プロピレングリ コールが皮有障害を起こさないことを健康な被検 者で確認したのち，トラニラスト溶液に $5 \%$ オレ イン酸および $5 \%$ プロピレングリコールを混合し イオン導入法を行い, 薬物送達への影響を検討し た．了解を得た患者の痄痕切除手術前にイオン導 入法を行い, 手術後切除された瘷痕の薬物濃度を 測定した。 その結果は，トラニラスト単独処置に くらへ，低い值にとどまった(表 1).

従来より, イオン導入法において薬物以外のイ オンの共存は, 電流が薬物以外のイオンに働き薬 物への作用効率が減少するため，薬物透過が低下 することが報告されている ${ }^{16)}$. 本研究でのトラニ ラスト透過量低下の原因も，同様の理由によるも のと考えている.

\section{展 望}

治療による患者への負担，すなわち薬物の全身 への副作用, 局所の皮虎障害, 疼痛, 疼痛を伴う 治療への精神的苦痛, 通院に要する時間あるいは 
費用の問題，各種治療による日常活動の制限，治 療の安全性への不安などをいかに軽減するかが, すべての疾患の治療法に求められている.これは, ケロイド肥厚性㓔痕においても同様であり, 比較 的限局された疾患であるため, 数週閒に一度の治 療で, 有効量の薬物が疼痛を伴わず局所のみに作 用するのが，理想的な治療法と思われる，筆者ら のイオン導入法による治療方法の開発は, これら の条件を満足していると思われるが，つぎの点に ついて，さらに研究を要すると考えている.

まず,イオン導入法に要する時間の短縮である. このために, 吸収促進剤その他の薬物を今後も検 討する予定である。 オレイン酸を混合したトラニ ラスト溶液では, かえって薬物送達量は低下して いたが，イオン導入法によりまず吸収促進剤を皮 周角質層に送達し, その後目的とする薬物の経皮 投与を行うのも一法と考えている。 また，ケロイ ド肥厚性痏痕は患者によってさまさまな形態を有 しており, すぺての痗痕に適合可能な薬液パッド の開発は，ぜひとも必要である，現在までは， Iomed 社製の 2 種類の薬液パッドを利用してき たが，大きさが適合しないため治療しにくいのが 現状である。

つぎに，新規の経皮薬物送達の手法を開発して も, 使用する治療薬の薬効により, 治療効果に限 界があると思われる。したがって，ケロイド肥厚 性癜痕の症状改善効果の可能性を有する他の薬物 での検討も必要と考えている.

\section{文 献}

1) Cohen K, Peacock EE : Keloid and hypertrophic scars. Plastic Surgery Vol. 1. General Plinciples. (ed. Sanders staff), W. B. Sanders Company, USA, 1990, p732-7476

2) 藤井 徽：ケロイド. 美容形成外科学. (難波雄哉, 塩 谷信幸, 長田光博·編), 南江堂, 東京, 1987, p 759766.
3）鬼塚卓弥：ケロイド治療。形成外科手術書. 南江堂, 東京, 1982, p 231-240.

4）冨士森良戟：保存的・放射線治療，図説臨床形成外科 講座第 1 巻創偒治嬑, 組緎移植. (添田周吾, 塚田貞夫, 大浦武彦・編)，メジカルビュー社，東京，1987，p 6063.

5）茂木定之, 谷 祐子, 生田義和：レーザー治療におけ るイオントフォレーシス麻醉の経験。広島医学 47 : 1444-1446, 1994.

6) Gangarosa LPSr, Osawa A, Ohkido M, Shimomura Y, Hill JM : Iontophoresis for enhancing penetration of dermatologic and antiviral drugs. J. Dermatol. $22: 865-875,1995$.

7) Costello CT, Jeske AH : Iontophoresis : applications in transdermal medication delivery. Phys. Ther. $75: 554-563,1995$.

8）茂木定之, 宇田宏一, 生田義和, 村上照夫, 矢田 登: イオン導入法によるケロイド治療の陚みートリアムシ ノロンアセトニドおよびトラニラストを用いて一。 DDS $11: 43-47,1996$.

9) Shigeki S, Murakami T, Kiyonaka G, Yata N, Ikuta Y: Transdermal iontophoretic delivery of triamcinolone acetonide: a preliminary study in hairless rats. Scand. J. Plast. Reconstr. Surg. Hand Surg. 30:177-181, 1996.

10) Berti JJ, Lipsky JJ : Transcutaneous drug delivery : a practical review. Mayo Clin. Proc. 70 : 581586, 1995.

11) Schmid MH, Korting HC: Liposomes : a drug carrier system for topical treatment in dermatology. Crit. Rev. Ther. Drug Carrier Syst. 11 : 97-118, 1994.

12) Touitou $E$, Junginger HE, Weiner ND, Nagai $T$, Mezei M: Liposomes as carriers for topical and transdermal delivery. J. Pharm. Sci. 83 : 1189-1203, 1994.

13）吉岡牧子, 村上照夫, 東 皚, 矢田 登, 茂木定之 · 他：マイクロダイアリシスによる経皮吸収の評価 (3) トラニラストの吸収改善. 日本薬学会第 116 年会薬成 学製剂学部会発表演題, 1996.

14) Koyama Y, Bando H, Yamashita F, Takakura Y, Sezaki $\mathrm{H}$ et al. : Comparative analysis of percutaneous absorption enhancement by d-limonene and oleic acid based on a skin diffusion model. Pharm. Res. $11: 377-383,1994$.

15) Lin SY, Duan KJ, Lin TC: Direct or indirect skin lipid-ordering effect of pyrrolidone carboxylate sodium after topical treatment with penetration enhancers. Biomed. Mater. Eng. 5 : 9-29, 1995.

16) Gupta SK, Kumar S, Bolton S, Behl CR, Malick AW : Optimization of iontophoretic transdermal delivery of a peptide and a non-peptide drug. J. Control Release 30:253-261, 1994. 